\title{
HEBREW TOPONYMS
}

\author{
By M. E. J. RIGHARDSON
}

\section{A. PLAGE NAMES AND PERSONAL NAMES}

The study of Hebrew toponomy has recently been set on its feet by Professor Yohanan Aharoni in the English edition of his survey of Biblical geography. ${ }^{1}$ The subject, to which he devotes a whole chapter, has usually been examined in comprehensive studies of Hebrew proper names and invariably personal names have then stolen the limelight. But with the increasing pace of Palestinian excavations more and more interest is being taken in the history of place names. Aharoni's chapter on toponomy is one of those additions to the English version of his book that make it much more than a translation of his earlier Hebrew work. $^{2}$

The linguistic importance of onomastica lies in their tendency to conserve older morphemes lost in the common vocabulary. Masterly studies are to hand for the literatures of Egypt, ${ }^{3}$ Assyria ${ }^{4}$ and Israel $^{5}$ and new research proceeds apace with new discoveries; in the last few years three theses have been written at Brandeis University concerned with Ras Shamra personal names. The first was concerned with the alphabetic personal names (Uejechi, I96I), the second a grammar of Hurrian from the Anatolian names (Bush, 1964) and most recently there has been a study of the Akkadian names (Kinlaw, rg66). ${ }^{6}$ At the same time a comprehensive independent investigation into all the personal names has been made in

1 Y. Aharoni, The Land of the Bible (translated from the Hebrew by A. F. Rainey), Burns \& Oates, London (r966).

2 'Ereș Yiśra'el Bitequpat Hammiqrah, Bialik Institute, Jerusalem (1962).

3 A. Gardiner, Ancient Egyptian Onomastica, Oxford University Press (1947).

- K. Tallqvist, Assyrian Personal Names, Societas Scientiarum Fennicae, Helsinki (19I4), reprinted G. Olms, Hildesheim (rg66).

5 M. Noth, Die israelitischen Personennamen im Rahmen der gemeinsemitischen Namengebung, Kohlhammer, Stuttgart (1928), reprinted G. Olms, Hildesheim (1966).

- Available on microfilm through University Microfilms, Ann Arbor, Michigan. 
Berlin and is now published. ${ }^{7}$ Although onomastic linguistic features may be seen as clearly in place names as in personal names, it is these latter that dominate the research scene. The main differences between the two are differences of detail (such as in compound names, which if personal are generally verbal sentences and if local contain two nouns) so that an independent study of place names is considered worth while.

The fundamental work in English was expanded from an essay written for the Kennicott Senior Hebrew Fellowship at Oxford in 1893 by George Buchanan Gray. ${ }^{8} \mathrm{He}$ freely acknowledged his dependence on the earlier German work of Eberhardt Nestle ${ }^{9}$ though he added a great deal that was new. Both books concentrate on those names containing divine elements and correlate the historical distribution of different names with the development of the religion of Israel. This was done again with conflicting and more radical conclusions by Henry Preserved Smith. ${ }^{10}$ It is more difficult to carry out such a correlation with place names. As much importance was attached to the name of a place as to the name of a person, but vacillating social customs affect personal names more immediately. Place names are more permanent and the conditions they reflect may long have ceased to exist.

Nevertheless, all that could be done in the way of cataloguing and classifying was done by Gray in a series of three articles in the Biblical Encyclopaedias that were published after his book, ${ }^{11}$ and he noted more recent discoveries, like the names from the Samaria Ostraca, there. From this groundwork, modern commentaries have built their articles. ${ }^{12}$ Not until 1930 was the

7. Frondahl, Die Personennamen der Texte aus Ugarit (Studia Pohl I) Pontifical Biblical Institute, Rome (1967). In addition we have H. B. Huffmon's Amorite Personal Names in the Mari Texts, John Hopkins University Press, Baltimore (1965), and a thesis on personal names from Elephantine is due to be completed under the supervision of Prof. E. Y. Kutscher in Jerusalem.

${ }^{8}$ G. B. Gray, Studies in Hebrew Proper Names, A. \& C. Black, London (1896).

9 E. Nestle, Die israelitischen Eigennamen nach ihrer Religionsgeschichtlichen Bedeutung, De Erven F. Bohn, Haarlem (1876).

10 'Theophorous Proper Names in the Old Testament' in Old Testament and Semitic Studies in memory of William Rainey Harper (ed. R. F. Harper et al.) I, Chicago University Press (1908) 35-64.

${ }_{11} H D B$ s.v. Names, Proper. EBi s.v Names (Place Names). ERE s.v. Names (Names, Hebrew).

${ }_{12}$ R. Abba, The Interpreters' Dictionary of the Bible (ed. G. A. Buttrick et al.) Abingdon Press, New York (1952) s.v. Name (Place Names). J. Taylor, Dictionary of the Bible (ed. F. G. Grant and H. H. Rowley) T. \& T. Clark, Edinburgh (1963) s.v. Name (Names). 
first and only linguistic analysis of all the toponyms of the Old Testament undertaken ${ }^{13}$ and this was before the decipherment of the Ugaritic archive.

In this paper ${ }^{14}$ we will examine the names of some of the towns of Canaan known from this archive. From them we may learn what significance the victorious people of Israel would have attached to place names and under what circumstances they would have changed them. It is also worthwhile to study the style of Hebrew topographical literature and compare it with what has been preserved at Ras Shamra.

\section{B. VARIANT READINGS IN DUPLICATE TEXTS}

I. Boundary Descriptions. The most abundant sources for names are administrative documents. While biographical histories, private letters and other prose narratives may tell far more about the location, lists of towns such as were always kept at administrative centres, boundary treaties and tribute levies are the best guides to the number of communities in a given area. This is the kind of material from which the second part of the book of Joshua is derived. This part, chapters $13-21$, has been called the pragmatic section and includes several phrases reminiscent of Ugaritic territorial descriptions.

One of the more interesting documents to come from the Royal Palace at Ugarit is a border treaty accompanied by a list of places demarcating the proper territorial limits. These documents have been used again when drawing up a ratification of the treaty between later rulers. ${ }^{15}$ The original deed was made between Niqmadu of Ugarit and Suppiluliuma of Garchemish and concerns the dispute over certain frontier towns between Ugarit and the state of Mukish. After a raid by a confederacy of rebels Suppiluliuma had granted to Niqmadu a frontier that would be more easily defended and the details were set out and recopied for ratification by the later rulers Mursilis II and Niqmepa. Thus the original documents may

13 W. Borée, Die alten Ortsnamen Palästinas, Eduard Pfeiffer, Leipzig (1930).

14 Read at the Old Testament Study Group of the Tyndale Fellowship, at Cambridge, July 1968.

${ }_{15}$ Principal edition of these texts by J. Nougayrol in PRU IV. RS 17.340 with simple name list RS $17.369 \mathrm{~A}$ (48-52), and ratification RS 17.237 with simple name list RS 17.62 and duplicate fragments RS 17.339A and RS I 7.366 (63-69).

D 
be compared with the later copies to see how they differed. ${ }^{16}$

It is immediately clear that the divergencies in these lists are frequent yet of minor importance. There is in fact, as far as the text is still legible, hardly any difference between the names themselves and there are few omissions. Those noted are Mount Nana, RS I7.340 rev. 6', which is omitted in RS I $7.62,23^{\prime}$, and the unusually long uninscribed gap which would be left if no restoration were made after Yalda at RS I 7.339A, $3^{\prime}$. Spellings may vary between texts; especially noteworthy is Bituhulibi (RS 1 7.366, I2') for Bituhuwili (RS I7.62 I'). This may throw light on Hebrew Mehebel for which Mahalab is proposed with LXX in Joshua I9:29. Also of note is the more common variation between like consonants (Kanga[ki(?)], RS I7.339A, 6' for [Kan]kaki RS 17. 62, 14') and between vowels (Alluli, RS I7.339A, $3^{\prime}$ for Allula RS I7.62, I I' and Hadamgi, RS I 7. 340 rev. $4^{\prime}$ for Hadamga, RS I 7.62, $2 \mathrm{I}^{\prime}$ ).

What is striking is the converse freedom the scribe exercised in glossing particular names or linking them with prepositions to express more accurately their relationship and order in the list. The most curt of these documents, RS.17.340, is never quite in the form of Noth's supposed 'name only' list from which he would consider treaty documents to have been compiled, ${ }^{17}$ $a d u$, 'as far as' occurring at least once and perhaps twice in the first two lines; yet the glossed texts add not only prepositions but also more significant prepositional phrases, as adi misari 'to the boundary' (RS I 7. 62, 2'), apparently missing in RS I 7.366, I2', adi mế, 'to the waters' (RS I 7.62, 3') and ša ina libbi tâmti, 'which is in the middle of the sea' (RS I 7.62, 25') omitted in RS I7.340, rev. $7^{\prime}$. Examination of this material shows clearly that a variant text, while following its own style whether listing or narrating may still preserve the material accuracy of its subject-matter. In comparing parallel Biblical texts of this nature, like the settlement tribal lists in Joshua, similar variants may be considered characteristic.

2. Town Lists. As well as this boundary contract, Ras Shamra has produced a good number of town lists. These were compiled for calculating the strength of the corvée which was drawn

${ }^{16}$ RS 17.62 is duplicated thus: lines $1^{\prime}-10^{\prime}$ RS 17.366 ; lines $7^{\prime}-21^{\prime}$ RS 17.339A; lines $17^{\prime}-25^{\prime}$ RS I 7.340 , rev. $I^{\prime}-7^{\prime}$ where the boundary was first described.

17 M. Noth, Das Buch Fosua ${ }^{2}$ J. C. B. Mohr, Tübingen (1953). 
from the kingdom. The amount of produce each town was to contribute or the number of days' work was stated and at the end of the tablet or at a ruled off section the total levy from a group was calculated. Usually this total is written in Akkadian rather than Ugaritic. Errors have been observed in the scribe's arithmetic, sometimes of a minor nature, as in A. Herdner, Corpus no. II3, vi: margin, 86 for 83; no. II9:i:24, 6 for 9; ii: 12,9 for 6 , and 7 for 9 ; ii:20, 7 for I I ii: 28,6 for 9 ; but elsewhere of greater measure as no. I I9:i:24, 2 I for $34 ; \mathrm{i}: 48$, 26 for $4 \mathrm{I}$; and v:I9, 79 for apparently 135 . This last error is particularly gross, and the number may refer to the first group of bow suppliers only, some 89 bows, when the error would be but Io. None of the arithmetical 'errors' in the book of Joshua approach quite the proportions of this Ugaritic text. In fact the scribe has shown competence which is exemplary in the systematic description of the Levitical cities (Jos. 21). The introduction, verses $4-7$, describes how every one of the four Levitical families is to receive cities from three of the tribes; the Kohathites descended from Aaron are to receive I3, the other Kohathites Io, the Gershonites I3 and the Merarites 12. When the details are given of how the division is to be made among each tribe and what cities will be allocated, verses 9-40, the tribal totals are always correct, the family totals agree with those stated in the introduction. Finally the grand total of Levitical cities is in fact $4^{8}$ as declared in verse $4^{\mathrm{I}}$. Similarly the list of defeated kings, Joshua 12:7-24, is given the correct total of $3 \mathrm{I}$. There are difficulties in the numerical summaries given with the tribal boundaries, Joshua $15^{-19}$, yet even here critics have given more attention to the errors than appreciation of the general accuracy. There is no clear explanation of 29 for an expected 36 at Joshua $15: 32$ but elsewhere in the Judah list there is only a single mistake, of one unit, 14 for I 5 at Joshua $15: 36$.

The Isaachar boundary (Jos. 19:17-23) totals 16 cities including 3 which the border but 'touches'. Elsewhere the numerical summary does not include every town mentioned. This probably arose because some of the places named in the boundary description were not towns within the territory proper. The figure of 22 for Asher may omit places 'touched', Carmel and Shihor Libnath and those mentioned to establish 
the direction of the boundary, Ramah and Hosah. Perhaps 3 towns already mentioned in the boundary description of Naphtali are omitted in the town list to avoid repetition so that the total I9 may be appropriate. Since, however, these examples are not basic administrative material like that at Ras Shamra but a literary reformulation, we are prevented from assessing from it the numerical accuracy of the scribe to quite the same degree.

3. Orthographic Variants. It has been noted that there are several towns in the Ugaritic lists that may be written with and without final $-y$. It is unlikely that this $-y$ is a phonemic termination. The simple form and the $-y$ form do not occur in the same list and so both may well refer to the same place. C. H. Gordon has explained the full forms as gentilics, ${ }^{18}$ but it is unusual to find such a form in a town list, and the Akkadian tablets from Ugarit are not so styled. Out of some 37 names that sometimes end in $-y$ only I I offend in that their $-y$ forms seem to be something other than the gentilic adjective. One cannot yet be identified in syllabic writing and 3 others are written imperfectly on shattered texts. With such paucity of evidence conjecture may seem hazardous but the fact stands that all the seven remaining names are written in Akkadian with final vowel $-a$. These are,

\begin{tabular}{|c|c|}
\hline $\begin{array}{l}g n^{e}(y) \\
u b r^{i}(y) \\
h l b(y) \\
m^{e} r b(y) \\
s m(n) g(y) \\
{ }^{\prime} m m k(y)\end{array}$ & $\begin{array}{l}\text { äl gana } \\
\text { äl ubura } \\
\text { äl halba (äl halbi in compound names) } \\
\text { äl ma'rapa } \\
\text { äl '̌ameqa, äl samniqa } \\
\text { äl enumaka }\end{array}$ \\
\hline
\end{tabular}

This then would exemplify in Ugaritic place names the phonetic development we see in the Hebrew personal name sáräy which by final monophthongization becomes sára. It is perhaps significant that no folk etymology is given for this change in the Hebrew text.

The lists of Joshua have not shown any such orthographic variants, compared with the names as listed in Numbers. All names ending in $-\hat{a}$ are written with $\boldsymbol{n}$ or $\boldsymbol{x}$. The spasmodic

${ }^{18}$ Ugaritic Textbook, Pontifical Biblical Institute, Rome (1965) §§ 8.52,53. 
writing of ציבון and atc., without matres lectionis is not well enough attested to show any tendency, especially when צritten both plene and defectiva. We may, however, note in passing שמהמה, which is written as inbers $32: 3$, corresponding to the Ugaritic simple pattern.

\section{THE MEANING OF NAMES}

New settlers would often change the name of their new home. Presumably this was because the former name was offensive to them or because they wished to commemorate in the new name a feature pertinent to their own experience. The significance of the original name may or may not have been apparent to them, though there is evidence that foreign invaders did often appreciate the name of a town they subdued.

Place names are generally classified according to their meaning, as we understand it. Many draw attention to physical features like Rabbah, Zoar (Ug. sǵrt), Gibeah (Ug. $g b^{e}$ ), Emek, Beer or Jabesh, Others describe the ecological environment as Eshkol or $\zeta m n$, or may commemmorate an historical event like Mahanaim (often a military event) or Mishpat. The many compound names are characterized by an initial morpheme of general significance which may be omitted in an abbreviated reference. House, Vineyard, Spring and Hillock are very well attested in Hebrew and Ugaritic texts in such a usage as well as being independent morphemes. In these instances Hebrew and Ugaritic share a common root, but this is not always so. The question is, if the Ugaritic scribe would write a Hebrew place name of which the root was not common to his own language by transliterating into his own script, or by translating, using a word with no phonetic correspondence to the original but of which the meaning was clear. har for example is very common in Hebrew place names, but the most appropriate translation in Ugaritic is $g b l$.

Some light is shed upon this from cuneiform sources, when ideograms are used in proper names. In personal names the sign ARAD which would regularly represent phonetic ardu is used at Ugarit for West Semitic $a b d u$. Similarly sIG $_{5}$ instead of signifying phonetic damāqu may represent $n^{e} m$. The very common sign IGI in place names is certainly used to represent 
' $n$ instead of regular $i n u$ and although this could be translation or transcription, since ' does not exist as an Akkadian phoneme, together with the other instances it is clear that translation did in fact take place. Here the Ugaritic scribe was most probably translating from his mother tongue and Akkadian was an acquired language.

But scribes translating into their mother tongue seem likewise to have understood foreign place names. Many names of Palestinian communities of the second millennium BG are contained in Egyptian records. One of these ${ }^{19}$ translated recently by J. A. Wilson ${ }^{20}$ is a list of Galilean towns which were subordinate to Ramesses II and which he 'passed through' on the Palestinian campaign of his eighth year. Only twelve of the original eighteen names are preserved at all and five of these are badly broken. M. Burchardt ${ }^{21}$ had earlier drawn attention to Jerusalem, for it is written with two determinatives, the regular foreign country sign (Gardiner no. N25) and also the greeting determinative (Gardiner no. A3o). In fact this sign would be used regularly after words for praise or respect, not corresponding to the semantic field of Hebrew $\zeta \mathrm{lm}$. Even though this gloss is approximate-for most glosses must be in the last analysis-it is clear that the Egyptian scribe, while not translating the Hebrew word into Egyptian, which he may well have done by $s n b$, has transliterated into hieroglyphs as well as he could $\left(s^{\prime}-v e-r-m\right)$ and shown his understanding of the name by adding an appropriate determinative.

The suggestion is vindicated by another name, $m^{\prime}-r-m$ which evidently represents Hebrew Marom and similarly has an extra determinative, the tall man (Gardiner no. A2 I), which would normally stand for phonetic $k^{\prime} i$ certainly not $\mathrm{rm}$, which would no more suggest the idea of height to an Egyptian than $5 l m$ would suggest greeting. K. A. Kitchen has posited a hitherto unknown Hebrew place *dlt-șlwl from Egyptian $d[r] t$-dniwr meaning 'door of the locust' and his argument for the equation is based on the same principle of a scribe transliterating, here

19 Ramesseum, list on W. side of N. tower of first pylon. Lepsius, Denkmäler Abth. III Blatt I56 and Text (ed. Sethe) III $127 f$.

${ }^{20} A \mathcal{N} E T^{2}, 256$.

21 M. Burchardt, Die altkanaanäische Fremdworte und Eigennamen in Ägyptischen, J. C. Hinrichs, Leipzig (1909-10). 
with particularly difficult phonetic correspondence, and then adding an extra determinative. ${ }^{22}$

If our understanding of these names is correct, it demonstrates a remarkable linguistic awareness on the part of some ancient scribes as well as a desire to convey the meaning of a place name.

In the Biblical narrative describing the conquest of Canaan, there is reference to the changing of names, but a comparison of all the changes does not reveal a distinctly Hebraic preference for certain name types. The classical example of what was understood to be a Hebrew renaming, from Jebus to Jerusalem has had to be withdrawn since it was discovered from the Tell el Amarna tablets that the place was known as URU sa-lim as early as the thirteenth century BC. From the five occurrences of the gloss there is no real evidence whether Jebus or Jerusalem was the Hebrew coinage, and on consideration it is more fitting for the invaders to know the city by the name of its formidable inhabitants than as a city of welcome!

There is a reference specifically to name changing in Numbers $32: 38$, where Baal Meon, of the cities of Judah is to be renamed. The Massoretes by their vocalization understand that Nebo also is to be renamed. If the etymology of the name suggested first by Noeldeke, from Arabic an-nabawah 'height' be accepted ${ }^{23}$ rather than the folk equation with the god $\mathrm{Nabu}$, religious scruples will not be offended and the renaming direction may refer only to Baal Meon. Unfortunately, no variant of this name omitting the pagan god is yet known; all the Biblical variants contain it, even if in rudimentary form. ${ }^{24}$ In fact the Massoretes seem to have tolerated Baal names much more in place names than in personal names. While names like Ishbaal were euphemistically expressed as Ishbosheth, there are some twenty Baal place names left unaltered in the text.

All the indications of the nature of the language of preconquest Palestine that we can glean from Moabite, Ugaritic and Early Aramaic lead us to suggest that it would have been comprehensible to a speaker of Biblical Hebrew. We must remember that the Aramaic of Rab Shakeh was not compre-

${ }^{22} \mathcal{F E A} 50$ (1964) $53 \mathrm{ff}$.

${ }_{23}$ ZDMG 188 (1942) 47 of.

${ }^{24}$ Beth Baal Meon (Jos. 13:1 7), Beth Meon (Jer. 48:23) and Beon (Nu. 32:3). 
hensible to Hebrew speakers as we may have suspected it would have been and frequently the closest of neighbours do not understand each other's language. ${ }^{25}$ But we can safely say that names given in this early Ganaanite would be more understandable to the Hebrews than, let us say, to the Egyptian and the Akkadian scribes. There may have been suggestions in the names that were unacceptable but we have little evidence that even so the name was purposefully changed. Although Israel was commanded to rid all Canaanite associations from the land, she did not completely change the map.

${ }^{25}$ E. Ullendorff, FSS 13 (1968) 127. 